\title{
Semmelweis 250 Klinikai Konferencia összefoglaló
}

\author{
Simon Botond \\ Semmelweis Egyetem, Klinikai Orvostudományok Doktori Iskola, \\ Semmelweis Egyetem, Fogorvostudományi Kar, Konzerváló Fogászati Klinika
}

A Semmelweis Egyetem alapításának 250 éves évfordulóját megkoronázó nemzetközi multidiszciplináris programsorozat 2020. november 9-10. között, a nemzetközi és hazai járványhelyzetre és szabályozásra tekintettel, online formában került megrendezésre, angol nyelven.

A szervezők célul tűzték ki, hogy a rendezvény a Semmelweis Egyetem komplex tevékenységét mutassa be a klinikai és elméleti orvostudomány számos területén az innovációtól a jövő orvostudományát bemutató technológiákig, amelyre közel hetven hazai és külföldi ismert és elismert előadó kapott meghívást, és 15 különböző szekcióban tartottak színvonalas előadásokat.

A Semmelweis 250 Klinikai Konferencia lehetőséget biztosított PhD-hallgatók számára is, hogy kutatási eredményeiket bemutathassák a nagyközönségnek. Közel 60 doktorandusz hallgató témájába nyerhettek bepillantást az érdeklődők, akik négy különböző szekció közül választhattak, mint például a pszichiátria, neurológia és magatartástudomány szekció, a kardiológia, hematológia, orvosi képalkotás szekció, bőrgyógyászat, intenzív terápia, közegészségügy és esetbemutatások szekció és végül, de nem utolsó sorban a gyermekgyógyászat, nefrológia és pulmonológia szekció. A PhD-hallgatók kutatásaik eredményét három percben mutatták be, amely után kettő perc állt a közönség és a zsưri rendelkezésére, hogy kérdéseiket feltehessék az előadóknak.

A számtalan izgalmas, érdekes és innovatív kutatómunka között a biztonság és emberi azonosítás témakör is helyett kapott. Dr. Simon Botond szakfogorvos, PhD-hallgató, igazságügyi orvosszakértő jelölt a $S z a ́ j-$ szkennerek alkalmazása egypetéjü ikrek azonositásra címü előadásában számolt be kutatásuk eredményeiről. Felfedezésük középpontjában a szájpadlás és a szájpadlás elülső részén található bordázat, az úgynevezett szájpadbordák állnak. A szájpadbordázat az elmúlt 130 év szakirodalma alapján egyedi karakterisztikát mutat, azonban a technológiai fejlettség korábban nem tette lehetővé, hogy digitális elemző és összehasonlító módszerekkel, nagy pontosságú digitális szájpadlásmintákat használva, nagyszámú populációban, reprodukálható módon vizsgálni és igazolni lehessen a megfigyeléseket. A kutatás minőségét tovább növeli, hogy a kutatócsapat genetikailag közel azonos, egypetéjú ikerpopuláció mintáit vizsgálta meg és hasonlította össze egymással és kimutatható fenotípusos eltéréséket keresett a szájpadláson. Kontrollcsoportként pedig nagyszámú kétpetéjü ikerpopuláció mintáit használták, akik gyakorlatilag egyszerre született testvéreknek minősülnek. Az eredmények alapján a kutatók megállapították, hogy a saját minták összehasonlított értékei, valamint az egypetéjü ikerpárok mintáinak összehasonlított értékei között szignifikáns különbség figyelhető meg. A saját minták és az ikerpár minták összehasonlításának értékei nem fednek egymásba és 99,999\%-os populációs lefedettséggel és 99\%-os konfidencia intervallumban gyorsan, egyszerüen és pontosan használhatók emberi azonosításra. Eredményeikból arra lehet következtetni, hogy amenynyiben genetikailag közel azonos egyedekben is szignifikáns különbség mutatható ki két minta összehasonlításakor, akkor genetikailag eltérő egyedek között a különbség legalább ekkora vagy nagyobb mértékü, szemben a saját minták összehasonlításával. Ebből következtetni lehet arra, hogy a szájpadlásmintázat az ujjnyomattal egyenértékű egyedi azonosításra alkamas biometrikus marker. Tömegkatasztrófa helyzet esetén, büntetésvégrehajtásban vagy migrációs válsághelyzetben a szájpadlásbordázat biometrikus azonosításra alkalmas, azonban, mint minden antemortem és postmortem összehasonlítás esetén referenciaadatra is szükség van. A kutatók kiemelték, hogy digitális fogminta-adatbázis létrehozásával jogi, kriminalisztikai, igazságügyi és katonai esetek is megoldhatók, amennyiben biometrikus azonosításra kerül sor.

Tömegszerencsétlenség során fontos a gyors és hatékony áldozatazonosítás, amelyhez a fogainkról és szájpadlásunkról készített minták hosszútávú, digitális tárolása jelentheti a megoldást. Biztonságtudatosságunk szempontjából elengedhetetlen, hogy rendelkezésre álljon az emberekról olyan információ, amely alapján beazonosíthatók katasztrófahelyzetben.

A kutató fontosnak tartja a fogorvos és fogtechnikus kollégák bevonását az adatgyưjjtésbe, amellyel gyorsan felépíthetővé válik egy fogászati minták tárolására alkalmas adatbázis. 
A Semmelweis 250 Klinikai Konferencia poszterprezentációs verseny dobogós helyezéseit, különdíjasait szekciónként hirdették ki. A bőrgyógyászat, intenzív terápia, közegészségügy és esetbemutatások szekcióban az első helyezést Dr. Szabó Marcell kapta, témájának címe: Lung Aeration Assessed by Ultrasound in the Prediction of
Postoperative Pulmonary Complications. A második helyezést Dr. Simon Botond kapta Application of intraoral scanner to identify monozygotic twins címú témájával. Dr. Pajtók Csenge pedig a harmadik helyezést érte el a The effect of high- $\mathrm{NaCl}$ intake on skin tissue remodeling címú poszterprezentációjával. 